\title{
TINJAUAN HUKUM ISLAM TERHADAP WEWENANG IMAM MASJID SEBAGAI WALI MUHAKKAM DALAM PERNIKAHAN BAWAH TANGAN
}

\author{
Moh. Bahropin Hafid¹, Muhammad Taufik ${ }^{2}$ \\ ${ }^{1}$ Mahasiswa Pascasarjana UIN Datokarama Palu \\ Email: baharuddinhafidz5@gmail.com \\ ${ }^{2}$ Dosen Fakultas Syariah UIN Datokarama Palu \\ Email: pencarikebenaran28@gmail.com
}

\begin{abstract}
Promiscuity among teenagers is one of the causes of underhand marriages using muhakkam guardians because the perpetrators of promiscuity are ashamed or afraid to report the incident to their family and relatives. In addition, the incident of religious conversion from Hinduism or Christianity to Islam is a factor that often occurs in Tolai village, because basically guardianship of parents other than Islam is not legal according to Islamic law, this causes the marriage process to be represented by a muhakkam guardian. There was a marriage problem that occurred in Tolai Village related to guardianship, a mosque imam married a girl to her partner because the girl did not have a nasab guardian or mujbir guardian because she was a convert, seeing this incident the mosque imam took steps to marry off the two couples without a valid marriage registration according to the law as stated in law number 16 of 2019 concerning marriage in article 2 paragraph 2 which reads: every marriage is recorded according to the applicable laws and regulations.
\end{abstract}

Keyword: Islamic Law, Authority, Mosque Imam, Guardian Muhakkam, Wedding

\begin{abstract}
Abstrak
Pergaulan bebas dikalangan remaja menjadi salah satu penyebab terjadinya pernikahan bawah tangan dengan menggunakan wali muhakkam karena para pelaku pergaulan bebas malu ataupun takut untuk melaporkan kejadian itu kepada keluarga dan saudara. Selain itu, peristiwa perpindahan agama dari agama Hindu atau Kristen keagama Islam adalah faktor yang sering terjadi di desa Tolai, karena pada dasarnya perwalian atas orangtua selain Agama Islam adalah tidak sah menurut Hukum Islam, hal ini menyebabkan proses pernikahan diwakilkan kepada wali muhakkam. Terdapat permasalahan Pernikahan yang terjadi di Desa Tolai terkait perwalian, seorang imam masjid menikahkan seorang gadis dengan pasanganya karena gadis tersebut tidak memiliki wali nasab atau wali mujbir karena mualaf, melihat kejadian ini imam masjid mengambil langkah untuk menikahkan kedua pasangan tersebut
\end{abstract}


tanpa adanya pencatatan perkawinan yang sah menurut undang-undang sebagaimana tertera dalam undang-undang nomor 16 tahun 2019 tentang perkawinan pada pasal 2 ayat 2 yang berbunyi: tiap-tiap perkawinan di catat menurut peraturan perundang-undangan yang berlaku.

Kata Kunci: Hukum Islam, Wewenang, Imam Masjid, Wali Muhakkam, Pernikahan

\section{A. Pendahuluan}

Perkawinan merupakan suatu hal yang penting dalam realita kehidupan umat manusia. Dengan adanya perkawinan rumah tangga dapat ditegakan dan dibina sesuai dengan norma agama dan tata kehidupan masyarakat. Dalam rumah tangga berkumpul dua insan yang berlainan jenis (suami istri), mereka saling berhubungan untuk mendapatkan keturunan sebagai penerus generasi. ${ }^{1}$

Pernikahan bukanlah hal yang sederhana, tidak cukup hanya berkumpulnya laki-laki dan perempuan dalam sebuah keluarga, dalam pernikahan banyak sekali hal yang harus dipahami dan dilalui. Mulai dari persiapan sebelum dilangsungkannya pernikahan hingga setelah pernikahan. Para ulama madzab sepakat bahwa pernikahan baru bisa dianggap sah jika dilakukan dengan akad, yang mencakup ijab dan qabul antara wanita yang dilamar dengan lelaki yang melamarnya, atau antar pihak yang menggantikannya seperti wakil dan wali, dan dianggap tidak sah hanya semata-mata berdasarkan suka sama suka tanpa adanya akad. ${ }^{2}$ Sahnya pernikahan merupakan awal mula untuk membina dalam keutuhan pernikahan tersebut sebagai ikatan yang sangat kuat. Untuk mewujudkan kuatnya ikatan perkawinan dan mewujudkan kehidupuan keluarga yang sakinah, mawaddah dan rahmah., maka sejak awal tata cara perkawinan diatur dengan syarat dan rukun tertentu. Membahas mengenai rukun pernikahan 2017), 1.

${ }^{1}$ Abdul Manan, Aneka Masalah Hukum Perdata Islam Di Indonesia (Jakarta:Kencana,

2 Muhammad Jawad Mughniyah, Fiqih Lima Madzab (Jakarta: Lenetera Basritama, 1996), 309. 
para ulama' fiqih berbeda pendapat, baik dalam jumlah maupun jenisnya. Namun, dibalik itu semua, juga ada beberapa kesamaan.

Dalam pernikahan yang ada di Indonesia ada beberapa istilah pernikahan yang tidak sesuai dengan ketentuan undang-undang, seperti halnya pernikahan di bawah tangan. Pernikahan di bawah tangan adalah pernikahan yang tidak di catatkan dan tidak dihadiri oleh pegawai pencatat nikah.

Menurut Ma'ruf Amin, Forum ijtima' Ulama Komisi Fatwa sengaja memakai istilah perkawinan bawah tangan karena istilah ini lebih sesuai dengan ketentuan agama Islam, perkawinan di bawah tangan yang termaksud dalam fatwa ini adalah perkawinan yang terpenuhi rukun dan syarat yang ditetapkan dalam fikih ataupun hukum Islam. Namun, perkawinan ini tanpa adanya pencatatan resmi di instansi terkait sebagaimana diatur dalam UU Nomor 16 Tahun 2019 Tentang Perkawinan.

Perkawinan dibawah tangan yang tidak dicatatkan dipandang tidak memenuhi ketentuan peraturan perundang-undangan dan sering kali menimbulkan dampak negatif terhadap isteri dan juga anak yang dilahirkanya terkait dengan hak-hak seperti, nafkah, hak waris dan lain sebagainya, tuntutan pemenuhan hak-hak tersebut manakala terjadi sengketa akan sulit dipenuhi akibat tidak adanya bukti catatan resmi perkawinan yang sah.

Terkait dengan masalah haram melakukan perkawinan di bawah tangan Ma'ruf Amin menegaskan bahwa hukum perkawinan yang awalnya sah memenuhi syarat dan rukunya yang awalnya pernikahan itu sah menjadi haram karena ada yang menjadi korban. Dengan demikian, haramnya itu datangnya belakangan, perkawinanya sendiri tidak batal, tetapi akan menjadi dosa karena ada yang terlantarkan akibat dari pernikahan semacam itu, sehingga dia berdosa karena menelantarkan isteri dan anaknya, sah tapi haram kalau sampai terjadi korban ${ }^{3}$

${ }^{3}$ Asrorun Ni'an Sholeh, Fatwa-Fatwa Masalah Pernikahan dan Keluarga (Jakarta: Graha Pramuda,2008), 147. 
Pernikahan yang terjadi dibawah tangan biasanya dilakukan oleh kedua mempelai dan keluarga dengan memanggil imam masjid sebagai penghulu karena masyarakat mempercayai imam masjid adalah orang yang tepat dalam melakukan pernikahan ini, padahal yang semestinya pernikahan semacam ini tidak boleh dilakukan mengingat dampak dan kerugian yang akan didapatkan jika ada permasalahan dalam pernikahan, Anak dan Istri tidak dapat menuntut hak-hak mereka karena pernikahan mereka di luar tanggung jawab dari Pemerintah.

Imam masjid seharusnya tidak menyarankan ataupun mengabulkan pernikahan semacam ini karena ada cara ataupun jalan yang telah diberikan oleh pemerintah melalui undang-undang jika dalam pernikahanya terdapat beberapa kekurangan. contohnya, wanita yang ingin menikah tetapi tidak memiliki wali dalam melangsungkan pernikahan maka sesuai dengan jalan yang diberikan oleh Negara melalui Undang-Undang Nomor 16 Tahun 2019 dan Kompilasi Hukum Islam mereka berhak mendapatkan wali yang dipersiapkan oleh Pemerintah yaitu Wali Hakim sebagaimana tercantum dala Pasal 1 huruf b KHI menyebutkan Wali Hakim ialah wali nikah yang ditunjuk oleh Menteri Agama atau pejabat yang ditunjuk olehnya, yang diberi hak dan kewenangan untuk bertindak sebagai wali nikah. mengingat kedudukan wali sangat penting dalam pernikahan. Bahkan, sah atau tidaknya suatu pernikahan bisa bergantung pada wali atau yang menikahkan karena pernikahan tanpa wali adalah tidak sah atau batal. Untuk itula seharusnya imam masjid tidak memiliki kompetensi dalam menikahkan wanita yang tidak memiliki wali, maka alangkah baiknya imam masjid menyarankan wanita yang mau menikah untuk mendaftarkan dirinya ke pengadilan dengan melakukan permohonan penetapan wali hakim untuk pernikahanya.

Dalam penetapan wali juga tidak seenaknya saja harus ada penyerahan yang dilakukan oleh wali nasab kepada wali yang lainnya seperti penyerahan wali nasab kepada wali hakim, tetapi jika wanita yang ingin menikah tidak memiliki wali nasab sama sekali, maka penyerahanya tetap kepada wali hakim 
terlebih dahulu tidak boleh langsung kepada wali Muhakkam sesuai dengan urutan perwalian.

Seperti halnya yang terjadi di Desa Tolai Kecamatan Torue, Kabupaten Parigi Moutong, tentang masalah perwalian bahwa seorang imam masjid menikahkan seorang gadis yang ingin menikah dengan pasanganya karena gadis tersebut tidak meiliki wali nasab atau wali mujbir karena mualaf, melihat kejadian ini imam masjid mengambil langkah untuk menikahkan kedua pasangan tersebut tanpa adanya pencatatan perkawinan yang sah menurut undang-undang sebagaimana tertera dalam undang-undang nomor 16 tahun 2019 tentang perkawinan pada pasal 2 ayat 2 yang berbunyi: tiap-tiap perkawinan di catat menurut peraturan perundang-undangan yang berlaku. Tetapi yang terjadi tidaklah demikian pernikahan tetap di laksanakan tanpa adanya serah terima dari wali nasab kepada wali muhakkam dengan alasan darurat segala sesuatu dalam jika pada keadaan darurat maka yang harampun bisa menjadi halal. Pandangan semacam ini seharusnya tidak boleh berkembang dikalangan masyarakat.

Kejadian yang hampir serupa juga terjadi yaitu seorang yang hamil di luar nikah kemudian kedua orang tuanya jauh dan tidak dapat di hubungi sedangkan wanita ini hanya memiliki saudari wanita, dan juga adik dari pada ibu kandungnya yang mengatakan bahwa ibu kandungnya sudah menyerahkan perwalianya kepada suami dari adik kandung ibunya tersebut sehingga pernikahan itu tetap di laksanakan. Seharusnya pernikahan semacam ini batal dan tidak sah.

Dari hal tersebut di atas penulis tertarik untuk melakukan penelitian tentang wali muhakkam tersebut apakah imam masjid memiliki wewenang dalam menikahkan wanita yang tidak memiliki wali nasab sama sekali sehingga imam masjid berani mengambil sikap demikian, untuk itu maka penulis akan melakukan penelitian tersebut dengan judul tinjauan hukum Islam terhadap wewenang imam masjid sebagai muhakkam dalam 
pernikahan bawah tangan (study kasus di Desa Tolai, Kecamatan Torue, Kabupaten Parigi Moutong).

\section{B. Pembahasan}

\section{Tinjauan Umum Tentang Perwalian}

Perwalian dalam pernikahan memang harus ada karena menentukan keabsahan ikatan sakral yang akan dijalani, ikatan sakral ini bukan hanya sekedar formalitas saja melainkan harus memiliki tujuan yang jelas, tujuan dari pernikahan adalah mewujudkan keluarga yang sakinah, mawaddah, dan rahmah.

a. Pengertian Perwalian

Beberapa konsep dan pengertian perwalian menurut hukum Islam adalah sebagai berikut :

1) Perwalian dalam istilah bahasa adalah wali yang berarti menolong yang mencintai. ${ }^{4}$ Kata perwalian berasal dari kata wali, dan jamak dari awliyah. Kata ini berasal dari bahasa arab yang berarti teman, klien, sanak atau pelindung. Dalam literatur fiqih Islam disebut dengan al-walayahi (alwilayah), orang yang mengurus atau yang menguasai sesuatu. Perwalian dalam istilah fiqih disebut wilayah, yang berarti penguasaan dan perlindungan. Seperti dalam penggalan ayat, "wa man yatwallallaha wa rasulahu” dan kata "ba'duhum awliya'u ba'din. Ayat 61 Surat At-Tawbah juga berarti kekuasaan atau otoritas (as-Sultah wal-Qudrah). Adapun perwalian dalam terminologi para fuqaha' (pakar hukum Islam), seperti disebutkan Wahbah al-Zuhayli ialah kekuasaan/otoritas yang dimiliki seseorang untuk secara langsung melakukan suatu tindakan sendiri tanpa harus bergantung pada izin orang lain.

2) Perwalian menurut fiqih ialah penguasaan penuh yang diberikan oleh agama kepada seseorang untuk menguasai dan melindungi orang atau

${ }^{4}$ Ahmad Warson Munawwir, Kamus al-Munawir (Jogjakarta: Pondok Pesantren alMunawwir, 1984), 1960. 
barang. Orang yang diberi kekuasaan perwalian disebut wali. ${ }^{5}$ Untuk memperjelas pengertian tentang perwalian, maka penulis memaparkan beberapa pengertian antara lain, perwalian yang berasal dari kata wali mempunyai arti orang lain selaku pengganti orang tua yang menurut hukum diwajibkan mewakili anak yang belum dewasa atau belum akil baligh dan melakukan perbuatan hukum. ${ }^{6}$

3) Sedangkan menurut Amin Suma perwalian adalah kakuasaan atau otoritas (yang dimiliki) seseorang untuk secara langsung melakukan tindakan sendiri tanpa harus bergantung ( terikat) atas izin orang lain. ${ }^{7}$ kepentingan bersama (bangsa atau rakyat) seperti waliyul amri (dalam arti Gubernur atau yang lainnya).

4) Sedangkam perwalian khusus ialah perwalian terhadap jiwa dan harta seseorang, seperti terhadap anak yatim. ${ }^{8}$

5) kamus praktis bahasa Indonesia, wali berarti orang yang menurut hukum (agama, adat) diserahi kewajiban mengurus anak yatim serta hartanya sebelum anak itu dewasa atau pengasuh pengantin perempuan pada waktu nikah (orang yang melakukan janji nikah dengan pengantin laki-laki). ${ }^{9}$

6) Menurut Ali Afandi menuturkan perwalian adalah pengawasan pribadi dan pengurusan terhadap harta kekayaan seorang anak yang belum dewasa, jika anak itu tidak berada dibawah kekuasaan orang tua. Jadi dengan demikian anak yang orang tuannya telah bercerai atau salah satu dari mereka meninggal dunia, ia berada dibawah perwalian. ${ }^{10}$

5 Soemiyati, Hukum Perkawinan dan Undang-undang Perkawinan (Undang-Undang no. 1 tahun 1974 tentang Perkawinan), (Yogyakarta: Liberty, 1986), 41.

${ }^{6}$ Soedaryo Soimin, Hukum Orang dan Keluarga, Perspektif Hukum Perdata Barat/BW, Hukum Islam dan Hukum Adat (Jakarta: Sinar Grafika, 2002), 60.

7 Muhammad Amin Suma, Hukum Keluarga Islam di Dunia Islam (Jakarta: PT Raja Grafindo Persada, 2005), 134.

${ }^{8}$ Dedi Junaedi, Bimbingan Perkawinan (Cet; 1, Jakarta: Akademika Pressindo. 2000), 104.

${ }^{9}$ Hartono, Kamus Praktis Bahasa Indonesia ( Jakarta : Rineka Cipta, 1996), 176.

10 Ali Afandi, Hukum Waris, Hukum Kleuarga, Hukum Pembuktian (Jakarta: Rineka Cipta, 1997), 156. 
7) Muhammad jawad al-Mugniyah memberi pengertian wali adalah seorang yang diberi kewenangan atau kekuasaan secara syar'i atas segolongan manusia, hal tersebut dikarenakan adanya kekurangan tertentu pada orang tertentu. ${ }^{11}$

8) Sedangkan Abdur Rahman al-Jaziri dalam kitabnya fiqih 'ala madzahibil 'arba'ah mendefinisikan wali dalam nikah bahwa:12 "Wali dalam nikah adalah orang yang mempunyai puncak kebijaksanaan atas keputusan yang baginya menentukan sahnya akad (pernikahan), maka tidaklah sah suatu akad tanpa dengannya, ia adalah ayah atau kuasanya dan kerabat yang melindungi, mu'tik, sultan dan penguasa yang berwenang."

9) Mustofa Hasan seirama dengan pernyataan dari Abdur Rahman al-Jaziri, beliau menyatakan wali dalam nikah adalah orang yang berhak menikahkan karena adanya pertalian darah secara langsung dengan pihak mempelai perempuan. ${ }^{13}$ Jadi wali dalam nikah adalah seorang laki-laki yang berwenang untuk menikahkan calon mempelai putri akibat hubungan darah, yang berhak menjadi wali adalah kelompok kerabat laki-laki lurus ke atas (ayah, kakek dan seterusnya), kelompok kerabat saudara laki-laki kandung atau saudara laki-laki seayah, kelompok kerabat paman (saudara laki-laki kandung ayah, saudara seayah, dan seterusnya), dan kelompok saudara laki-laki kandung kakek.

Menurut hukum Islam perwalian terbagi dalam tiga kelompok. Para ulama mengelompokan perwalian sebagai berikut :

a) Perwalian terhadap jiwa ( al-walayah 'alan-nafs )

b) Perwalian terhadap harta ( al-walayah alal-mal)

c) Perwalian terhadap jiwa dan harta (al-walayah 'alan-nafsi wal-mali ma'an).

Perwalian dalam nikah tergolong ke dalam al-walayah 'alan-nafs, yaitu perwalian yang bertalian dengan pengawasan ( al-ishraf) terhadap urusan

${ }^{11}$ Muhammad Jawad al-Mughniyah, Fiqih Lima Madzab (Jakarta: Lentera, 2011), 345.

${ }^{12}$ Abdur Rohman al-Jaziri, Fiqih 'Ala Madzahibil Arba'ah (Jilid; 4, Kairo: Darul Haditst, 2004), 26.

${ }^{13}$ Mustofa Hasan, Pengantar Hukum Keluarga (Bandung ; Pustaka Setia, 2011), 98. 
yang berhubungan dengan masalah-masalah keluarga. Hal ini berdasarkan pengertian semantik, kata wali dapat dipahami alasan hukum Islam menetapkan ayah sebagai orang yang paling berhak untuk menjadi wali dalam kepentingan anaknya, karena ayah adalah orang yang paing dekat, siap menolong, serta mengasuh dan membiayai anak-anaknya.

Jika tidak ada ayahnya barulah hak perwaliannya digantikan oleh keluarga dekat lainnya dari pihak ayah, dan seterusnya. ${ }^{14}$ Setiap pernikahan harus memerlukan wali. Adanya wali merupakan salah satu rukun untuk sahnya suatu pernikahan, disamping zawjun (suami), zawjatun (istri), wali, shahidayn (dua orang saksi) dan ijab qabul. Ditetapkannya wali sebagai salah satu rukun keabsahan perkawinan bukanlah ingin mempersulit pelaksanaan perkawinan, melainkan didasari oleh sejumlah nas yang sahih. Didalam sejumlah hadits diterangkan mengenai keharusan adanya wali dalam pernikahan.

b. Wali Muhakkam Dalam Hukum Islam

Kata muhakkam diambil dari bahasa Arab yang asal katanya hakamayahkumu-hukman-wahukumatan, yang artinya memegang perintah, mengepalai, menghukumkan, menjatuhkan sanksi hukuman ${ }^{15}$. Mahkamatun artinya tempat berhakim. ${ }^{16}$ Menurut kaidah ilmu tasrif, kata hakama adalah timbangan (wazan) fa'ala, sehingga kata hakama menjadi hakamayahtahkiman. Kata-kata tahkim dalam bahasa Indonesia yang berarti mengangkat hakim, menjadikan hakim. ${ }^{17}$ Wali muhakkam dalam perkawinan Islam ialah seseorang yang diangkat oleh kedua calon suami istri untuk bertindak sebagai wali dalam akad nikah mereka. Apabila suatu pernikahan yang seharusnya dilaksanakan dengan wali hakim, padahal tempat itu tidak ada wali hakimnya, maka pernikahan tersebut dilangsungkan dengan wali muhakkam. Caranya

\footnotetext{
14 Dedi Supriadi, Fiqih Munakahat Perbandingan (Bandung : Pustaka Setia,2009), 32.

15 Muhammad Idris al-Marbawi, Kamus al-Marbawi (Surabaya: Dar al-Ihya, t,.t). 142.

16 Ibid., 143.

17 Depdikbud, Kamus Besar Bahasa Indonesia (Jakarta: Balai Pustaka, 1994), 884.
} 
ialah kedua calon suami istri mengangkat seseorang yang ahi dalam memahami tentang hukum-hukum pernikahan untuk menjadi wali dalam pernikahan mereka tersebut. Adapun dasar hukum yang berkaitan dengan wali muhakkam dalam hukum Islam,

Menurut Imam Nawawi menyatakan bahwa Imam Syafi'i mengatakan apabila ada perempuan yang tidak punya wali lalu dia menunjuk seorang lelaki untuk menjadi wali. Lalu si lelaki menikahkannya, maka hukumnya boleh. ${ }^{18}$ Selain Imam an-Nawawi, Imam al-Qurthubi juga beliau mengemukakan gagasannya, ia berkata bahwa jika perempuan yang tinggal ditempat yang tak ada sultan dan tidak ada pula mempunyai wali, maka penyelesaiannya dapat ia serahkan kepada tetangga yang dipercayainya untuk mengakadkannya. Dalam keadaan demikian tetangga tersebut telah menjadi wali. Karena setiap orang tentu perlu kawin, tetapi dalam melaksanakannya hendaklah sebaikbaiknya yang dapat di kerjakan. ${ }^{19}$ Kemudia pertanyaan yang muncul apakah wali yang dipilih oleh wanita tersebut mengetahui tentang munakahat atau hukum tentang perkawinan.

Dalam hubungan ini Malik berkata tentang perempuan yang kondisinya lemah, ia boleh dikawinkan oleh orang yang diserahi urusannnya, karena ia tidak dapat pergi kepada sultan. Jadi seolah-olah sultan tidak berada di tempatnya, sehingga seluruh orang Islam secara umum dapat bertindak sebagai walinya.

Imam Syafi'i berpendapat bahwa apabila dalam masyarakat terdapat perempuan yang tidak mempunyai wali, lalu ia mewalikannya kepada seorang laki-laki untuk menikahkannya, maka hukumnya boleh. Karena hal itu adalah merupakan tindakan yang mengangkat hakim. Dan orang yang diangkat sebagai hakim sama kedudukannya dengan hakim itu sendiri. ${ }^{20}$

\footnotetext{
18 Imam Nawawi, Raudatut at-Talibin (juz; v, Beirut: Darul Alam, 2003), 398.

19 Ibid, 398.

${ }^{20}$ Sayyid Sabiq, Fiqih Sunnah. 27.
} 
Imam Taqiyuddin al-Hushaini al-Dimasyqi mengatakan, Yunus bin Imam Husaini meriwayatkan dari Syafi'i bahwa jika dalam suatu masyarakat ada seorang wanita yang tidak memiliki wali sama sekali, lalu ia menguasakan atau mewakilkan perkaranya kepada seorang laki-laki, termasuk dalam hal proses pernikahan, maka hukumnya adalah boleh. Sebab hal itu termasuk pelimpahan kekuasaan dan status orang yang dilimpahi kekuasaan itu sama seperti hakim. Selain itu Imam al-Nawawi juga mengatakan, menurut alMawardi jika seorang wanita tidak punya wali sama sekali, maka ia memiliki tiga pilihan. Pertama, ia tidak menikah. Kedua, ia bisa menikahkan dirinya sendiri karena alasan darurat. Ketiga, ia bisa menguasakan atau menyerahkan urusanya kepada seseorang, kemudian orang itulah yang menikahkannya. ${ }^{21}$

Imam Syasyi mengatakan, bahwa dalam masalah seorang wanita tidak mempunyai wali sama sekali, ia boleh menguasakan kepada seorang ulama fiqih yang ahli ijtihad. Pelimpahan kekuasaan seperti itu hukumnya adalah boleh dan sah, sehingga pernikahannya pun boleh, tetapi dengan syarat pihak yang di limpahi kekuasaan tersebut harus kepada orang yang memang patut untuk memberikan keputusan, dan ini cukup sulit untuk ditemuka di zaman sekarang. Pernikahan nya sah apabila ia menyerahkan urusannya kepada orang yang adil (terjaga kehormatan dirinya), walaupun tidak sampai sebagai mujtahid. Itulah pendapat yang dikutip oleh Yunus bin Abdul A'la, seorang ulama yang jujur.22

Syeikh al-Jaziri menyatakan bahwa hakim boleh menikahkan wanita atas izin dan restu wanita itu setelah jelas tidak ada penghalang pernikahan, tidak ada wali, atau ada wali yang menolak menikahkan atau lokasinya berjauhan. Berbeda dengan pendapat para imam diatas, wali muhakkam juga bisa di tinjau menggunakan maqasidu al-syari'ah adalah makna-makna dan tujuan-tujuan yang ditetapkan bagi syariat dalam seluruh hukum-hukumnya

${ }^{21}$ Syaikh Muhammad Hafizh Ali al-Syuwaisyi, Tuhfah al-'Urusy wa bil Hajah al-Nufus, terj. Abdul Rosyad Shiddiq, Kado Pernikahan (Jakarta; Pustaka al-Kautsar, 2005), 51.

${ }^{22}$ Abdur Rahman al-Jaziri, Fiqih 'Ala Mazahibil Arba'ah. ,419. 
atau pada umumnya, atau tujuan dari syariat, atau rahasia-rahasia yang ditetapkan Allah SWT (al-syari') bagi setiap hukum dari hukum-hukumnya. ${ }^{23}$

Menurut Abu Ishaq al-Syatibi bahwa kemaslahatan itu terbagi menjadi tiga tingkatan yaitu al-Daruriyat, al-Hajiyat, dan al-Tahsiniyat. Kemaslahatan tersebut merupakan hasil dari pembacaan, sebagaimana yang dikatakan oleh Syathibii 24 , yaitu :

a) Hifzu ad-Din,

b) Hifzu an-Nafs,

c) Hifzu al-Aql,

d) Hifzu al-Nasl,

e) Hifzu al-Mal.

Pernikahan dengan menggunakan wali muhakkam jika di kaitkan dengan tingkatan maqasidu al-syari'ah bagian hifzu ad-Din, dan hifzu an-Nasl memang kurang begitu relevan, dikarenkan pernikahan seperti ini cenderung melanggar tujuan pernikahan, dan pernikahan menggunakan wali muhakkam juga menimbulkan madarat yang sangat besar.

\section{Penyebab terjadinya pernikahan dengan Imam Masjid sebagai wali Muhakkam dalam pernikahan bawah tangan}

Sebagaimana dijelaskan dalam penjelasan pada Bab sebelumnya bahwa pernikahan melalui Imam Masjid sebagai wali muhakkam merupakan salah satu bentuk perkawinan yang dilakukan tanpa dicatatkan secara resmi melalui Pegawai pencatat nikah. Fenomena keabsahan pernikahan melalui Imam Masjid sebagai wali muhakkam ditengah-tengah lebih populer dengan sebutan nikah sirri, merupakan pernikahan yang dilaksanakan sesuai dengan syarat rukun nikah dalam Islam, tetapi tidak di catatkan di Kantor Urusan Agama (KUA) atau Petugas Pencatat Nikah (PPN). Dinamakan sirri karena dilangsungkan secara diam-diam, tertutup, rahasia atau sembunyi-sembunyi

${ }^{23}$ Ishaq al-Syatibi, al-Muwafaqat fi Ushul al-Syari'ah ( Juz;II, Beirut: Dar al-Kutb al'Ilmiyah, t. t.), 217.

${ }^{24}$ Ibid., 325. 
tanpa adanya publikasi.

Pernikahan melalui Imam Masjid sebagai wali muhakkam ini pada sebagian masyarakat Muslim di Indonesia telah dikenal dan marak dipraktikkan. Namun sampai saat ini dalam masyarakat masih terdapat keragaman pemahaman tentang terminologi dan konsep pernikahan melalui Imam Masjid sebagai wali muhakkam. Hal ini dapat dipahami karena pernikahan melalui Imam Masjid sebagai wali muhakkam dilakukan penyuluhan dan sosialisasinya yang juga belum menyeluruh. Demikian juga dengan konsepnya, sebagian para ustadz dan masyarakat umumnya belum memiliki kejelasan dan kesamaan rumusan.

Sebagian besar menurut persepsi mereka (pasangan nikah melalui Imam Masjid sebagai wali muhakkam), mempunyai pengertian bahwa secara legal formal (fikih) Islam dapat dinyatakan sah. Hal ini didasarkan pada alasan bahwa pada saat peresmian nikah bawah tangan semacam itu semua syarat dan rukun yang telah ditentukan telah terpenuhi. Semua rukun yang dimaksud itu ialah adanya mempelai laki-laki dan perempuan, wali (yang menikahkan), dua orang saksi, adanya akad ijab qabul atau transaksi pernikahan, dan ada yang menambah lagi dengan harus adanya mas kawin (mahar). Hal-hal tersebut dianggap oleh kebanyakan pasangan nikah melalui Imam Masjid sebagai wali muhakkam sebagai keharusan bagi sah tidaknya suatu pernikahan secara Islam. Sedangkan berkaitan dengan pencatatan di KUA dan adanya publikasi (yang biasanya dilaksanakan dalam bentuk walimah/resepsi).

Seperti halnya yang terjadi di desa Tolai Kecamatan Torue Kabupaten Parigi Moutong. Pernikahan menggunakan wali muhakam terjadi karena beberapa faktor :

1. Faktor Pergaulan Bebas

Faktor pergaulan bebas salah satu penyebab terjadinya pernikahan bawah tangan dengan menggunakan wali muhakkam karena para pelaku pergaulan bebas malu ataupun takut untuk melaporkan kejadian itu kepada 
keluarga dan saudara, mereka terpaksa untuk melakukan pernikahan itu di luar daerah mereka dan meminta imam masjid untuk menikahkanya.

Seperti hasil wawancara penulis dengan saudara berinisial H.N sebagai berikut:

"pada waktu itu kami menjalin kasih hampir 2 tahun tetapi pada waktu itu pasangan saya hamil sebelum saya nikahi dan saya berinisiatif untuk menikahinya dan menemui orangtuanya tetapi pasangan saya takut untuk melaporkan hal ini kepada kedua orangtuanya sehingga saya dan pasangan saya mengambil jalan yang pintas, pada saat itu saya belum memahami bahwa pernikahan tanpa wali dari perempuan itu tidak sah jadi menurut saya wali dari pasangan saya adalah imam masjid itu sendiri, dan Alhamdulillah beberapa tahun kami menikah kami kembali ke rumah dan menceritakan semua kepada kedua orangtua dan kami dinikahkan kembali karena menurut mereka pernikahan kami tidak sah"25

Seharusnya pernikahan awal yang menggunakan wali muhakkam tidak harus dilakukan oleh kedua pasangan mempelai karena sangat merugikan kedua belah pihak. Padahal keadaan seperti ini dapat diselesaikan secara kekeluargaan, karena kedua pasangan sudah melakukan perbuatan Zina yang mengakibatkan dosa besar dan hamil diluar Nikah serta dosa setelah menikah menggunakan wali muhakkam karena itu tidak sah menurut Agama dan Hukum yang berlaku di Indonesia.

Seperti hasil wawancara yang dikatakan oleh Tokoh Agama

Komarudin:

"Hal itu seharusnya tidak boleh terjadi imam masjid harus berhati-hati dalam menentukan hukum boleh dan tidak boleh sah dan tidak sah, secara otomatis kalau ditinjau dari hukum Agama dan Negara sudah pasti pernikahan semacam ini batal dan tidak sah, pasangan yang seharusnya sudah terlanjur terjerumus dalam perbuatan zina seharusnya ditolong dengan melegalkan perkawinanya di KUA. Menikah di KUA juga sudah gratis dan tidak meghabiskan biaya yang banyak hanya cukup membeli makanan seperlunya untuk dimakan bersama itu sudah cukup, jadi seharusnya kalau kita tokoh Agama ingin menolong pemuda dan pemudi islami terhindar dari perbuatan zina kita juga perlu megetahui makna dan maksud yang tekandung dalam sebuah hukum

${ }^{25}$ H.N, Informan, wawancara, Tolai, 7 juli 2021 
dan aturan bukan selalu menggunakan dalil Drurat". ${ }^{26}$

Berhubungan dengan hal ini penulis beranggapan bawa seharusnya para imam masjid dan juga para mempelai yang akan melangsungkan pernikahan harus paham betul apa saja syarat dan rukun sahnya sebuah pernikahan bukan hanya mengandalkan dalil dalil yang seharusnya tidak relevan lagi dengan kejadian seperti ini.

2. Faktor tidak direstui oleh kedua orang tua

Faktor penyebab Pernikahan yang di lakukan dengan wali muhakkam adalah karena tidak direstui oleh orang tua sehingga para mempelai mengambil jalan pintas untuk tetap mempertahankan cinta mereka, dari beberapa kasus yang terjadi faktor tidak direstui oleh kedua orangtua salah satu faktor yang sering terjadi, karena faktor inilah imam masjid dengan alasan darurat mengambil langkah untuk menikahkan mereka agar tidak terjadi perzinahan antara muda mudi di daerah tersebut karena jika keadaan seperti ini akan menimbulkan kemudaratan yang lebih buruk lagi

Seperti hasil wawancara penulis kepada Informan yang bemarna Zyad: "kami menikah tanpa adanya restu dari orang tua tapi kami tidak bisa saling memisahkan begitu saja karna hubungan kami sudah berjalan sangat lama dan kami saling mencintai,tapi hubungan kami tidak direstui karena ada beberapa faktor sehingga kami tidak dibolehkan untuk menikah sehingga saya dan istri saya kawin lari menurut istilah orang disini, setelah saya kawin lari didesa ini beberapa bulan kemudia diketahui oleh orangtua kami, dan kami di perkenankan untuk hidup bersama dengan syarat kami dinikahkan secara sah kembali di KUA( Kantor Urusan Agama)"27

Permaslahan soal faktor tidak direstui orang tua juga ini mejadi salah satu penyebab terjadinya pernikahan dengan wali muhakkam karena ada alasan-alasan yang membuat orang tua tidak merestui hubungan mereka, tetapi alasan tidak direstuinya pernikahan dengan wali nasab juga tidak dapat dijadikan alasan yang syari untuk membolehkanya seseorang yang ingin menikah langsung menggunakan wali muhakkam karena didaerah ini sudah

${ }^{26}$ Komarudin, Informan, wawancara, Tolai, 9 juli 2021

${ }^{27}$ Zyad, Informan, wawancara, Tolai, 7 juli 2021 
jelas memiliki KUA yang tidak begitu jauh dari desa tersebut,

Penulis juga melakukan wawancara kepada salah satu warga yang bernama Rosmiati yang mengetahui kejadian ini:

"Pada wakktu kejadian itu saya sudah menyarankan kepada yang bersangkutan untuk menikah menggunakan wali hakim saja yang ada di KUA tetapi yang bersangkutan tidak mau melakukan pernikahan di KUA karena beranggapan pasti harus mengurus Surat kartu keluarga dan lain-lain sedangkan orang tuanya tidak menyetujuinya, saya juga sudah memberikannpenjelasan soal tidak sahnya perkawinan mereka tapi mereka berpandangan sah saja karena pernah membaca buku soal bolehnya menikah tanpa adanya wali". ${ }^{28}$

\section{Faktor perpindahan agama}

Faktor perpindahan agama dari agama Hindu atau Kristen keagama Islam adalah faktor yang paling terjadi, karena pada dasarnya perwalian atas orangtua selain Agama Islam adalah tidak sah dan bisa dikatakan perwalian nasabnya sudah terputus maka secara otomatis wanita yang akan masuk keagama Islam tidak memiliki wali nasab Lagi,

Seperti hasil waawancara penulis kepada informan yang berinisial K.S:

"Saya dulu beragama hindu dan saya memiliki pasangan yang beraga islam dan saya ingin masuk islam mengikuti agama pasangan saya, tetapi karena perpindahan agama saya tidak memiliki wali dan saya juga tidak paham soal permasalahan wali karena saya menikah tidak menurut aturan Negara dan saya menikah hanya dengan aturan agama islam saja, umur saya juga tidak muda lagi jadi tidak memikirkan menikah dengan menggunakan wali hakim atau menikah di kantor KUA suami saya juga tidak pernah memberitahu saya soal permasalahan wali jadi saya merasa biasa-biasa saja dan orang disekitar saya tidak mempermasalahkan itu"29

Seharusnya pernikahan semacam ini tidak dapat dilakukan karena wali seorang mualaf adalah wali hakim yang sudah dsiapkan oleh aturan Negara. Namun untuk menjadi wali nikah haruslah memenuhi persyaratan terlebih dahulu. Adapun syarat menjadi wali nikah adalah laki-laki, beragama Islam, Akil, Baliqh, dan Adil. Apabila tidak terpenuhi salah satu unsurnya, orang

\footnotetext{
${ }^{28}$ Rosmiati, Informan, Wawancara, Tolai, 9 juli 2021

${ }^{29}$ K.S, Informan, wawancara, Tolai, 7 juli 2021
} 
tersebut tidak memenuhi syarat sebagai wali dan tidak bisa menjadi wali nikah. Berdasarkan pasal 22 KHI menyatakan bahwa apabila wali tidak memenuhi syarat maka hak perwalian wali nikah akan bergeser kepada wali nikah derajat lain. ${ }^{30}$

Seringkali calon mempelai wanita mualaf dan baru saja masuk Islam kesulitan memenuhi rukun nikah ini. Ayah kandung yang menjadi wali nasab dan paling berhak menikahkan anak perempuannya tidak bisa menjadi wali akibat beragama Non-Islam sehingga tidak memenuhi syarat menjadi wali nikah. Bila terjadi keadaan seperti itu maka calon mempelai wanita dapat meminta bantuan wali hakim sebagaimana Pasal 23 KHI yang menyatakan bahwa Wali hakim dapat bertindak apabila wali nasab tidak ada ${ }^{31}$.

Berdasarkan dari beberapa peraturan diatas sudah sangat jelas bahwa kalau memang seorang mualaf tidak memiliki wali untuk menikah maka wali dari seorang mualaf ini adalah wali hakim yang sudah disiapkan oleh Negara, Negara sudah sangat mempermudah urusan soal perkawinan tidak adalagi unsur bayar membayar jika pernikahan itu dilakukan di KUA kecuali pernikahan ini dilakukan diluar dari KUA maka ada biaya transportasi yang harus diberikan kepada pegawai KUA.

Kejadian pernikahan semacam ini sangat sungguh memperihatinkan karena seharusnya seorang mualaf harus kita perlaukan secara istimewa sebab dia rela untuk mninggalkan agama sebelumya untuk memeluk agama Islam seperti halnya yang dikatakan oleh tokoh agama komarudin:

"Seharusnya kita para pemuka Agama harus mengistimewakan para mualaf yang ingin memeluk agama islam dengan menggunakan jalur pernikahan, bukan malah membuat mereka terjerumus dalam perzinahan yang pada dasarnya mereka tidak mengetahui persoalan hukum wali dalam islam, walaupun alasanya mereka sudah berumur ataupun sudah tua tetap kita harus menikahkan mereka dengan cara yang legal menurut Agama dan Negara. Karena pernikahan semacam ini akan berdampak kepada kedua calon mempelai dan kepada keturunan-

${ }^{30}$ H. Abdurrahman SH.MH,Kompilasi Hukum Islam (Jakarta: Akademi Pressindo,2010), 119.

31 Ibid., 119. 
keturunanya". 32

\section{Faktor Jarak keberadaan wali}

Jarak menjadi salah satu faktor yang membuat seoran mempelai perempuan tidak memiliki wali, karena di daerah Tolai adalah sentra bisnis perdagangan dan juga pertanian banyak orang yang merantau ke daerah Tolai untuk mencari rezeki atau uang sehingga mereka tinggal sendiri di Desa Tolai, setelah lama tinggal mereka memilih menetap di perantauan. Orang tua dari wanita juga sudah tidak ada dan tidak mengetahui walinya yang lain.

Seperti hasil wawancara penulis dengan informan bernama zahrah latifah:

"Saya perantau dari daerah Kalimantan, saya tidak memiliki saudara kandung ayah dan ibu saya sudah lama meninggal dunia dan saya tidak mengenali saudara dari ayah saya, saya sudah lama tinggal di daerah ini dan menetap disini dan tidak memiliki sanak saudara sehingga saya tidak tahu memiliki wali nasab atau tidak dalam pernikahan. ${ }^{33}$

Dari hasil wawancara peneliti dengan informan ternyata jarak wali dan keberadaan wali menjadi permasalahan dalam perwalian sehingga mempelai menyerahkan perwalianya kepada imam masjid.padahal cara ini adalah cara yang tidak tepat dan perlu diberikan informasi yang lebih tepat dan pemahaman yang membuat mereka tidak salah memahami soal penyerahan wali.

Adapun hasil observasi dan wawancara yang penulis lakukan dengan tokoh masyarat bernama maduri mengatakan:

"Alasan yang seperti itu kan sudah tidak relevan lagi jika digunakan dizaman sekarang ini Karena semua sudah canggih tidak perlu mengirim surat atau mendatangi wali nasab secara langsung kekampung halamnya, cukup menggunakan hubungan via telepon sudah bisa melakukan penyerahan wali kepada yang ingin menikah, itupun penyerahan wali sudah dianggap sah jika yang menyerahkan itu betulbetul wali nasabnya, dengan adanya WA juga menjadi salah satu penentu dengan menggunakan video call kita sudah dapat mengetahui bahwa

32 Komarudin, Informan, Wawancara, Tolai 10 juli 2021.

${ }^{33}$ Zahra latifa,Informan, wawancara, Tolai, 7 juli 2021. 
benar yang menyerahkan perwalian itu adalah wali nasabnya"34

Pada hakikatnya penunjukan imam masjid yang berperan sebagai wali muhakkam dalam melangsungkan akad pernikahan bukanlah tanpa penyebab, penyebab yang timbul tanpa adanya interfensi dari pihak lain, melainkan timbul dari pelaku itu sendiri.

Adapun penyebab yang timbul dari kejadian nikah dengan menggunakan peran imam masjid sebagai wali muhakkam dalam pernikahan adalah : pertama, ingin menolong dari perbuatan zina. Kedua, mengikuti sunah rasul agar menyegerakan menikah bagi yang sudah mampu. Ketiga, sesuai pemahaman imam masjid bahwa menikah menggunakan wali muhakkam tanpa menginformasikan wali nasab adalah sah atas dasar jarak lebih dari 1 Safar.

Beberapa alasan yang dikemukakan oleh imam masjid tersebut membuktikan bahwa imam masjid diduga salah dalam memahami kajian tentang hukum perkawinan yang sah terutama dalam hal wali.

Imam masjid bersikeras mempertahankan pendapatnya dengan landasan beliau mendapatkan informasi terkait sahnya pernikahan tanpa wali jika telah melampaui batas jarak minimal 1 safar dari keterangan gurunya saat beliau mengaji. Alasan lain yang memperkuat pendapat imam masjid tersebut ialah alasan pernikahan sebagai ajang untuk menghindari perbuatan maksiat (zina).

Dari hasil observasi dan wawancara penelitian penulis, penulis berpendappat bahwa ada beberapa aspek yang menyebabkan imam masjid menikahkan mempelai tanpa penyerahan wali nasab;

1. Mungkin saja imam masjid pada saat menerima pelajaran dari gurunya dia dalam keadaan tidak memungkinkan sehingga imam masjid salah untuk menafsirkan soal hadis yang di sampaikan oleh gurunya dan ilmu yang didapatkan otomatis lain dari pada sumber yang diajarkan oleh gurunya.

${ }^{34}$ Maduri , Informan, Wawancara, Tolai, 8 Juli 2021. 
2. Keterbatasan imam masjid dalam hal mengetahui hukum perkawinan secara universal dan konprenhensif. Dalam hadits yang berkenaan dengan wali nikah, yaitu Artinya: "Dari Sulaiman bin Musa dari Zuhri, dari Urwah dari Aisyah, sesungguhnya Nabi Muhammad Saw telah bersabda: "Barang siapa di antara perempuan yang menikah tanpa izin walinya maka nikahnya batal. Karena apabila terjadi persetubuhan maka baginya (perempuan yang dinikahi) berhak atas mahar dengan sebab dihalalkannya farjinya. Demikian pula apabila terjadi pertentangan (tentang walinya) maka sulthan adalah wali bagi seorang yang tidak mempunyai wali.35" Nampaknya imam masjid kurang mengerti substansi dari kandungan hadis tersebut, sehingga mengalami kerancauan dalam berfikir. Dalam konteks hadis ini imam masjid beranggapan dalam hal syaariat sultan adalah pemimpin umat atau wali umat atau wali sultan yaitu imam masjid atau orang yang mengerti tentang pernikahan.

3. Imam masjid hanya memusatkan fikirannya pada kondisi sosial dari calon pasangan pengantin. Kondisi sosial yang dimaksud ialah dapat berupa menyegerakan menikah karena mempelai laki-laki dianggap sudah mampu atau menyegerakan pernikahan karena takut kaduanya berbuat zina. Ini adalah pandangan sosial filosofis. Seharusnya imam masjid tidak hanya memperhatikan pandangan sosial filosofis saja melainkan harus mengaitkan dan mempertimbangkan tentang keabsahan nikah ditinjau dari segi agama dan Negara.

4. Imam masjid tidak mengetahui rujukan pasti sebagai dasar hukum menikah menggunakan wali muhakkam meskipun wali nasabnya ada

5. Jarak satu safar yang dibuat dasar hukum utama imam masjid untuk melangsungkan pernikahan menggunakan wali muhakkam tanpa menginformasikan wali nasabnya adalah tidak sah karena sudah tidak relevan lagi digunakan pada zaman modern saat ini semua orang hampir memiliki alat komunikasi dan kalau memang wali nasab tidak memiliki alat

${ }^{35}$ Abu Daud, Sulaiman bin Asy'ats. Sunan Abi Daud. (Dar Al-Fikr: Beirut, t.th.), 88. 
komunikasi seharusnya imam masjid ataupun mempelai menghubungi pemerintah desa dimana orang tua mempelai tinggal dan atau menghubungi kerabat terdekat

\section{Tinjauan Hukum Islam Terhadap Wewenang Imam Masjid Sebagai Wali Muhakkam Dalam Pernikahan Bawah Tangan}

1. Wewenang Imam Masjid sebagai wali muhakkam

Berkenaan dengan imam masjid sebagai wali muhakam di Desa Tolai Karena permasalahan tidak adanya wali sebenarnya bukanlah permasalahan yang begitu darurat. Masih ada jalan pernikahan yang lebih legal yang sudah dipersiapkan oleh pemerintah dan itu sangat mudah untuk dilakukan oleh setiap warga Negara, beberapa faktor seperti yang sudah penulis kemukakan di atas rupanya menjadi alas an kenapa pernikahan menggunakan wali muhakkam ini bias terjadi.

Seperti halnya Hasil wawancara penulis kepada salah satu imam masjid yaitu:

"Pernikahan yang dilakukan oleh para mempelai terkait soal wali muhakkam sebenarnya sah-sah saja karna pada dasarnya melakukan pernikahan sesuai dengan syariat islam pernikahan yang terjadi di Desa Tolai ini tidak terlalu sering terjadi, karena pernikahan menggunakann wali muhakkam terjadi karena kasus-kasus tertentu seperti kedua mempelai tidak direstui oleh kedua orangtuanya, adanya perubahan Agama dari agama Kristen atau hindu ke agama Islam dank karena putusnya hubungan nasab seorang mempelai wanita dengan orang tuanya, pergaulan bebas dan jarak yang jauh, maka imam masjid atau orang yang paham soal perkawinan boleh saja menikahkanya. ${ }^{36}$

Padahal permasalahan persoalan wali sudah diatur dalam agama Islam dari Al-quran,Hadis dan kompilasi hukum islam tetapi pandangan imam masjid sangat bertentangan dengan aturan jadi tidak ada alasan yang syar'i bagi siapapun juga termaksud imam masjid untuk menikahkan seseorang yang tidak memiliki wali.

Tetapi yang terjadi di Desa Tolai sangat bertentangan dengan syariat

${ }^{36}$ Imam Nasrowi, Imam Masjid Tolai, wawancara, Tolai, 2 juli 2021 
islam dan juga hukum perkawinan Sebagaimana hasil wawancara penulis dengan salah satu Imam masjid sebagai berikut:

"Pernikahan menggunakan Imam masjid sebenarnya sah-sah saja jika semuanya terpenuhi seperti saksi, wali yang diangkat, mahar, dan mempelai laki-laki dan perempuan. Karena pada dasarnnya pernikahan menggunakan wali muhakkam ini adanya alasan kedaruratan seperti susahnya menghubungi seorang wali yang jauh sehingga pernikahan dapat di berlangsungkan untuk menghindari perzinahan. Pernikahan yang dulu pernah terjadi di daerah ini di karenakan jarak orang tua wali sangat jauh dan karena keterbatasan ekonomi wali mempelai wanita tidak memiliki handphone untuk di hubungi, dan mempelai wanita tidak mengetahui apakah wali yang lain masih hidup atau tidak karena wali nasabnya sudah meninggal. sehingga dengan alasan inilah untuk menghindari perbuatan yang tidak diinginkan maka imam masjid menikahkan mempelai dengan syarat-syarat perkawinan. ${ }^{37}$

Pandangan dari imam diatas bertolak belakang dengan salah satu tokoh Agama di Desa Tolai yaitu Komarudin sebagaimana hasil wawancara peneliti dengan beliau:

"Sebenarnya pernikahan menggunaan wali muhakkam itu boleh tetapi ada hal-hal tertentu yang membolehkan yaitu kalau memang betul-betul wali nasabnya sudah tidak ada dan wali hakim juga tidak ada di daerah tersebut, baru pernikahan itu dianggap sah jika menggunakan wali muhakkam dengan dalil darurat karena betul-betul sudah tidak ada lagi wali yang lain, tetapi jika didaerah tersebut masih ada wali hakimya maka pernikahan menggunakan wali muhakkam dianggap tidak sah dan yang melakukan dianggap telah melakukan perzinahan, maka dari itu sebenanrya sangatlah perlu adanya bimbingan soal perkawinan dan penggunaan perwalian di Desa Tolai ini,"38

Penggunaan wali muhakkam sebenarnya pernikahan menggunakan wali yang paling akhir jika sudah tidak ada pilihan lain yaitu ketika wali nasab dan wali hakim sudah tidak ada di daerah tersebut.

Pernikahan yang menggunakan wali sebenarnya harus sesuai urutan yang telah diatur yaitu Wali Nasab terlebih dahulu Sebagaimana yang termaktub dalam Q.S al-Baqarah: 232 berbunyi :

${ }^{37}$ Matori, Imam Masjid, wawancara, Tolai, 1 juli 2021

${ }^{38}$ Komarudin, Tokoh Agama, Wawancara, 1 juli 2021 


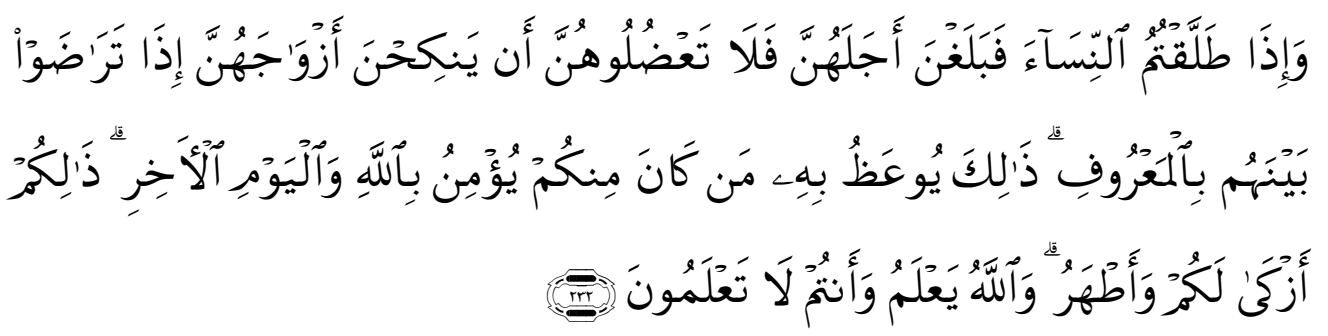

Terjemahnya:

"Apabila kamu mentalak isteri-isterimu, lalu habis masa iddahnya, Maka janganlah kamu (para wali) menghalangi mereka kawin lagi dengan bakal suaminya, apabila telah terdapat kerelaan di antara mereka dengan cara yang ma'ruf. Itulah yang dinasehatkan kepada orang-orang yang beriman di antara kamu kepada Allah dan hari kemudian. itu lebih baik bagimu dan lebih suci. Allah mengetahui, sedang kamu tidak mengetahui ${ }^{39 "}$

Ayat diatas sudah mengindikasikan seseorang yang menikah harus menggunakan wali karna jika pernikahan itu tidak menggunakan wali maka hukumnya menjadi tidak sah. Dan wali yang dimaksud diatas adalah wali nasab dari calon mempelai perempuan

Kemudia dalam ayat yang lain juga disebutkan sebagai berikut :

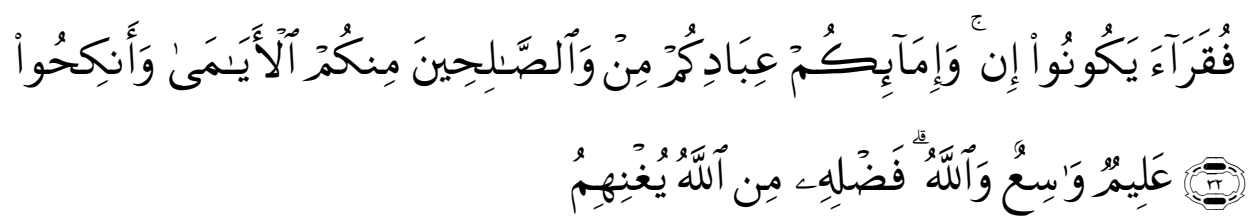

Terjemahnya:

"Dan kawinkanlah orang-orang yang sendirian diantara kamu, dan orang-orang yang layak (berkawin) dari hamba-hamba sahayamu yang lelaki dengan hamba sahayamu yang perempuan. Jika mereka miskin allah akan memampukan mereka dengan karunianya dan allah maha luas pemberianya lagi maha mengetahui ${ }^{40}$.

Dari kedua ayat Alquran di atas sudah menjelaskan bagaimana pernikahan harus adanya wali, dan wali yang dimaksud dalam Alquran itu

${ }^{39}$ Departemen Agama RI, al-Qur'an dan Terjemah Yayasan Penyelenggaraan Penerjemah atau Penafiran al-Qur'an, (Jakarta: Bumi Restu, 1979), 34.

40 Ibid., 319. 
sendiri adalah wali Nasab dari mempelai itu sendiri dan jika tidak ada wali hakimlah yang berhak menjadi wali bagi dia.

Pernikahan tanpa menggunakan wali juga sangat bertolak belakang dengan hadis-hadis dari Nabi Muhammad S.A.W yang diriwayatkan oleh Abu Daud yaitu:

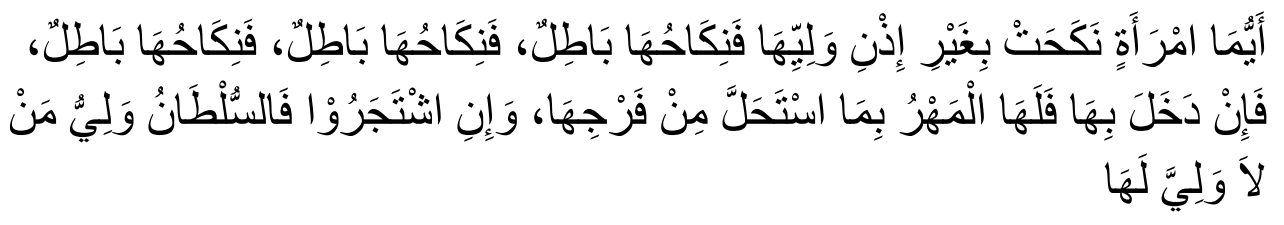

Artinya :

"Barang siapa di antara perempuan yang menikah tanpa izin walinya maka nikahnya batal. Karena apabila terjadi persetubuhan maka baginya (perempuan yang dinikahi) berhak atas mahar dengan sebab dihalalkannya farjinya. Demikian pula apabila terjadi pertentangan (tenang walinya) maka sulthan adalah wali bagi seorang yang tidak mempunyai wali". ${ }^{4}$

Berdasarkan hadis di atas status wali sangat urgen dalam pernikahan oleh sebab itu tidak bisa menggunakan wali muhakkam apabila ada wali nasabnya. Jika mengacu kalimat sultan atau penguasa hanya bisa bertindak sebagai wali jika urutan wali yang paling berhak tidak ada, namun hal ini dilanggar oleh kedua calon mempelai maupun oleh imam masjid yang tiba-tiba bertindak sebagai wali dalam pernikahannya, jika wali nasab dari calon pengantin itu ada maka terlebih dahulu harus menggunakan wali nasab dan tidak boleh menggunakan wali ditingkat yang dibawahnya, jika wali nasab memang benar tidak ada, atau ada namun adhal untuk menjadi wali, maka sultan (dalam hadist ini) baru bisa bertindak sebagai wali.

Namun dalam aturan yang berlaku sultan adalah seorang kepala KUA yang telah diamanati oleh undang-undang. kriteria sebagai sulthan bukanlah sangat remeh, yang ditunjuk sebagai sulthan bukanlah sembarang orang, dan bukan orang biasa pula, melainkan memiliki pengetahuan agama yang sangat

${ }^{41}$ Abu Daud, Sulaiman bin Asy'ats. Sunan Abi Daud. (Dar Al-Fikr: Beirut, t.th.), 88. 
luas, memiliki kredibilitas dan integritas baik, dan juga adil. ${ }^{42}$ Seperti hadis Nabi Muhammad SAW yang di riwayatkan oleh imam Ahmad Bin Hambal

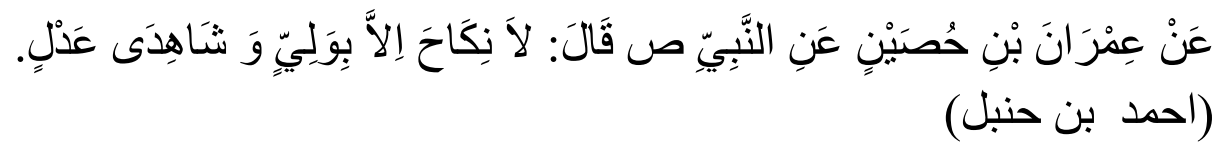

Artinya:

"Dari Imran Ibn Husein dari Nabi Saw bersabda: "Tidak sah pernikahan kecuali dengan wali dan dua orang saksi yang adil"(HR.Ahmad Ibn Hambal). 43

Kemudian hadis riwayat Ahmad juga sebagai penguat pendapat penulis bahwa pernikahan tanpa wali itu tidak sah.

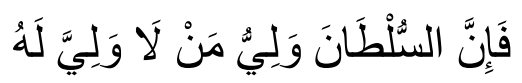

Artinya:

"Sungguh penguasa adalah wali bagi perempuan yang tidak memiliki wali. (HR.Ahmad)"44.

Kemudian hadis nabi Muhammad berikut ini juga ikut memperjelas dan mempertegas bahwa tidak ada pernikahan tanpa adanya wali

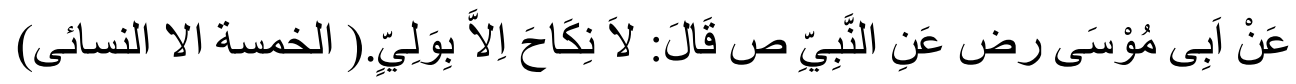

Artinya:

Dari Abu Musa RA dari Nabi SAW, beliau bersabda, “Tidak ada nikah melainkan dengan (adanya) wali". (HR. Khamsah kecuali Nasai) ${ }^{45}$.

Kemudia hadis dari abu dawud juga menjadi landasan batalnya pernikahan tanpa adanya wali.

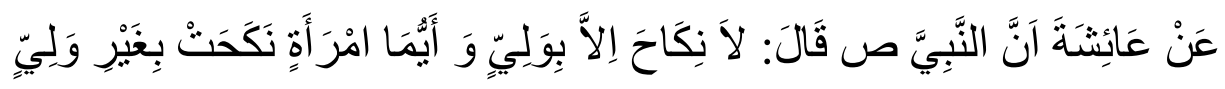

42 Hussein Bahreisy, Pedoman Fiqih Islam, (Surabaya: al-Ikhlas, 1981), 231.

${ }^{43}$ Bakri A. Rahman dan Ahmad Sukardja, Hukum Perkawinan Menurut Islam, UndangUndang dan Hukum Perdata, (Jakarta: PT. Hidakarya Agung, 1981), 28.

${ }^{44}$ Ibid., 28.

${ }^{45}$ Ibid., 29. 


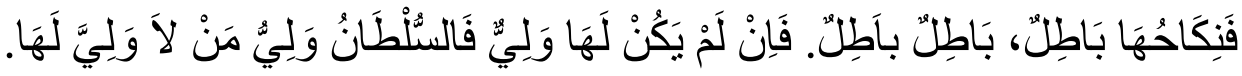

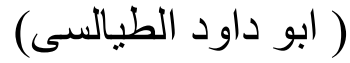

Artinya:

Dari'Aisyah bahwasanya Nabi SAW bersabda,"Tidak ada nikah melain kan dengan (adanya) wali, dan siapasaja wanita yang nikah tanpa wali maka nikahnya batal, batal, batal. Jika dia tidak punya wali, maka peng uasa (hakimlah) walinya wanita yang tidak punya wali".(HR. Abu Dawud Ath-Thayalisi) ${ }^{46}$.

Dari hadis nabi Muhammad di atas sudah menjelaskan bagaimana islam sangat mementingkan wali dalam hal pernikahan. Sampai nabi Muhammad juga sudah memberikan opsi lain jika wali nasab tidak ada maka wali hakimlah atau penguasalah yang berhak untuk menggantikan wali nasabnya. Jadi sudah jelaslah Alquran dan hadis diatas menjadi acuan bahwa pernikahan tanpa adanya wali itu sangatlah tidak sah menurut hukum Agama ataupun Hukum Negara.

2. Pengelompokan Wali Pernikahan

Pernikahan menggunakan wali muhakkam menurut para pelaku pernikahan adalah untuk menghindari zina padahal pendapat seperti ini tidak dapat dipertanggung jawabkan islam sudah mengatur sedemikian rupa tata cara pernikahan yang baik dan benar bukan hanya benar menurut syariat islam tapi benar juga dalam hukum positif yang berlaku di Negara Indonesia, Indonesia menganut system Demokrasi tetapi Sistem Hukum Pernikahan yang dibangun sesuai dengan Hukum Islam terkhusus dalam pernikahan Indonesia juga sudah menerbitkan peraturan pernikahan yaitu Kompilasii Hukum Islam, Soal urutan wali dalam pernikahan sudah diatur dalam Kompilasi Hukum Islam sehingga urutan itu tidak boleh dilanggar, dalam Kompilasi Hukum Islam tidak memuat adanya wali Muhakkam.Kompilasi Hukum Islam memuat soal itu yakni urutan wali dalam suatu pernikahan terdiri dari:

${ }^{46}$ Asy-Syaukani, Nail al-Autar (Mesir: Mustafa al-Babi al-Halabi wa-Auladuhu, t.t.), 135. 
a. Wali nasab terdiri dari empat kelompok dalam urutan kedudukan, kelompok yang satu didahulukan dari kelompok yang lain sesuai erat tidaknya susunan kekerabatan dengan calon mempelai wanita. Pertama : kelompok kerabat laki-laki garis lurus keatas yakni ayah, kakek dari pihak ayah dan seterusnya. Kedua : kelompok kerabat saudara laki-laki kandung atau saudara laki-laki seayah dan keturunan laki-laki mereka. Ketiga : Kelompok kerabat paman, yakni saudara laki-laki kandung ayah, dan keturunan laki-laki mereka. Keempat : Kelompok saudara laki-laki kandung kakek, saudara laki-laki seayah dan keturunan laki-laki mereka.

b. Apabila dalam satu kelompok wali nikah terdapat beberapa orang yang sama berhak menjadi wali, maka yang paling berhak menjadi wali ialah yang lebih dekat derajat kerabatnya dengan calon mempelai wanita.

c. Apabila dalam satu kelompok sama derajat kerabatnya, maka yang paling berhak menjadi wali nikah kerabat kandung dari kerabat yang hanya seayah.

d. Apabila dalam satu kelompok derajat kerabatnya sama, yakni sama-sama derajat kandung atau sama-sama derajat kerabat seayah, mereka samasama berhak menjadi wali nikah dengan mengutamakan yang lebih tua dan memenuhi syarat-syarat wali. ${ }^{47}$

Dari pengelompokan wali diatas sudah sangat jelas bagaimana Agama Islam sangat detail mengatur soal urutan perwalian tetapi yang terjadi di Desa Tolai sangat bertentangan menurut Hukum Fiqih pernikahan ataupun Kompilasi Hukum Islam. Imam Masjid langsung mengambil alih tanpa adanya persetujuan dari wali nasab atau wali hakim di daerah itu yang seharusnya imam masjid harus memahami kedudukanya sebagai wali. Kapan dirinya dapat bertindak sebagai wali dan dan dia tidak dapat bertindak sebagai wali.

Para ulama fiqih telah mengurutkan hak perwalian sesuai urutannya, jika urutan tersebut dilanggar tanpa alasan yang mendasar maka nikahnya tidak sah, dan wali Muhakkam berada pada urutan terakhir sesudah wali

${ }^{47}$ Dapertemen Agama RI, Kompilasi Hukum Islam (Jakarta : Karya Anda, 2000), 27 
hakim atau wali sultan. al-Allamah syekh Zainuddin Bin Abdul Aziz alMilibari urutannya berpindah kepada wali hakim sebagai berikut, jika semua wali nasab dan ashabah tidak ada, atau walinya ghaib, jauh dan sulit untuk dijangkau (disini perlu kajian dengan dikaitkannya dengan sulit untuk dijangkau. ${ }^{48}$

Untuk permasalahan jarak dizaman modern saat ini sudah tidak bisa lagi dijadikan alasan bolehnya menikah dengan menggunakan wali muhakkam. Setiap masyarakat pedesaan maupun perkampungan hampir semua menggunakan alat komunikasi, berbeda pada zaman dahulu sulit untuk menghubungi wali yang jauh dari seorang mempelai, maka harus menempuh jarak yang jauh untuk menemui wali dan memintanya untuk menikahkan.

Sekarang dengan adanya kecanggihan teknologi elektronik dibidang komunikasi terkhusus handphone ini salah satu yang sangat mempermudah urusan pernikahan jika jarak dari wali nasab itu jauh, mempelai hanya tinggal menghubungi seorang wali dan meminta persetujuanya untuk menyerahkan kekuasaan untuk diberikan kepada wali hakim yang akan melangsungkan pernikahan.

Untuk permasalahan soal seseorang yang ingin menikah tetapi tidak memiliki wali karena putus perwaliannya disebabkan perpindahan agama dari Agama sebelumnya ke Agama Islam, maka Hadis nabi Muhammad juga sudah menjelaskan soal peraturan mengenai walinya seperti hadis yang sudah penulis terangkan diatas. Sehingga alasan-alasan yang dibangun para mempelai pernikahan dan juga Imam masjid yang menikahkan gugur dengan sendirinya dan pernikahanya dianggap tidak sah menurut hukum Agama dan Negara.

Dari penjabaran Alquran dan Hadis di atas sudah jelas bahwa dapat disimpulkan imam masjid ini telah mengingkari urutan para wali dan tidak memperhatikan pentingnya wali nasab sebagai urutan wali yang utama dan

${ }^{48}$ Abdur Rohman al-Jaziri, Fiqih 'Ala Madzahibil Arba'ah (Jilid; 4, Kairo: Darul Haditst, 2004), 26. 
pertama, imam masjid ini seharusnya mengetahui bahwa wali hakim atau muhakkam adalah urutan wali terakhir, setelah urutan wali di atasnya sudah tidak dijumpai keberadaannya maka wali muhakkam ini baru bisa bertindak sebagai wali. Dan pernikahan yang seperti ini menurut penulis adalah terdapat cacat hukum didalamnya bahkan dianggap tidak sah karena melanggar ketentuan yang ada. Selain itu maqasidu al-Shari'ah juga digunakan sebagai alat tinjau pada pernikahan yang dilakukan dengan menggunakan wali muhakkam , jika ditinjau menggunakan tingkatan hifdu al-Din, dan hifdu alNasl sangatlah bertentangan.

Sebagaimana yang penulis uraikan adalah sebagai berikut:

a. secara hifdu al-Din (memelihara agama), imam masjid sudah tak memperhatikan dengan pemeliharaan agama melalui pernikahan, imam masjid lebih cenderung mempermudah agama dengan melakukan penyelewengan melalui pernikahan yang jelas-jelas tidak dibenarkan menurut aturan yang ada, sehingga peran agama dalam melindungi pernikahan sangatlah remeh dan wujud pemeliharaan agama tidaklah tercapai.

b. Sedangkan secara hifdu al-Nasl (menjaga keturunan), dalam Islam tentu menganjurkan terjaganya keturunan melalui jalan pernikahan yang sah sehingga tanpa adanya kerancauan nasab yang tidak jelas. Jika penulis amati pernikahan yang dilakukan dengan menggunakan peran imam masjid sebagai wali muhakkam sangat bertentangan dengan hifdu al-Nasl ,pernikahan seperti ini penulis anggap tidak sah, pernikahan yang tidak sah bisa disamakan dengan perzinaan dan akan timbul kerancauan nasab. Hasil dari pernikahan akan timbul adanya keturunan, jika keturunan itu perempuan maka nasab dari anak tersebut ikut dengan ibunya, namun imam masjid dan kedua calon mempelai sudah terlanjur menganggap pernikahan mereka adalah sah sehingga bapak biologis dari anak tersebut menjadi wali dalam pernikahan, yang seharusnya pernikahan yang 
demikian itu menggunakan wali hakim, dan akan terjadi pernikahan tidak sah secara beruntut dan berturut-turut.

Dengan menggunakan tinjauan hukum Islam diatas maka penulis beranggapan dan menarik sebuah kesimpulan pernikahan semacam itu tidak dapat dilakukan oleh imam masjid kecuali imam masjid mendapatkan mandat kekuasaan langsung dari wali hakim untuk menikahkan maka imam masjid boleh menikahkanya.

3. Status wewenang dan Keabsahan Pernikahan Menggunakan Wali Muhakkam Dalam Pernikahan Bawah Tangan

a. Melihat dari kasus yang telah terjadi di Desa Tolai yang sesuai dengan faktor-faktor yang telah penulis jabarkan diatas serta sesuai dengan hasil penelitian yang peneliti lakukan membuktikan bahwa Imam Masjid tidak memiliki wewenang sama sekali untuk menikahkan siapapun juga dengan alasan darurat atau agar menolong mereka agar tidak berbuat zina, karena pada dasarnya permasalahan yang terjadi di Desa Tolai masi memiliki Opsi lain untuk menikahkan mereka yaitu dengan menggunakan Wali Hakim jadi dengan dasar ini penulis beranggapan Imam Masjid Tidak memiliki wewenang Untuk menikahkan

b. Status keabsahan dari pernikahan yang terjadi dengan menggunakan wali muhakkam sudah jelas tidak memiliki wewenang dan berimbas kepada ketidakabsahan dalam pernikahan tersebut karena pernikahan yang terjadi di Desa Tolai sudah cacat dalam hal Perwalian, padahal KUA sangat dekat dengan Desa Tolai sehingga tidak ada alasan bagi wali muhakkam untuk menikahkan mempelai yang akan menikah karena Wali Hakim di Daerah tersebut masih ada, kecuali daerah tersebut sama sekali tidak ada wali hakim barulah imam masjid ataupun Tokoh Agama dapat mengambil alih untuk menikahkan dengan status wali muhakkam. 


\section{Penutup}

Dari pembahasan yang telah penulis paparkan, dapat ditarik kesimpulan sebagai berikut :

1. Penyebab pernikahan bawah tangan dengan menggunakan peran imam masjid sebagai wali muhakkam ini adalah sebagai berikut:

a. Imam masjid ingin menolong pemuda dan pemudi dari Pergaulan bebas yang menyebabkan perbuatan zina.

b. Perindahan Agama(Mualaf) sehingga tidak adanya wali nasab

c. Sesuai pemahaman imam masjid bahwa menikah menggunakan wali muhakkam tanpa menginformasikan wali nasab adalah sah atas dasar jarak lebih dari 1 safar.

d. Tidak adanya restu dari orang tua, sehingga imam masjid bergerak sebagai wali muhakkam

2. Secara hukum Islam, pernikahan bawah tangan menggunakan peran imam masjid sebagai wali muhakkam yang terjadi di desa Tolai bisa dihadapkan pada dua dasar pertimbangan.

a. Menurut al-Qur'an dan hadist. Pernikahan yang dilakukan tidak sesuai dengan al-Qur'an dan hadis karena tanpa ada izin dari wali nasabnya dan larangan bagi perempuan untuk menikahkan dirinya sendiri.

b. Menurut qawl fuqaha, mayoritas ulama' fiqih berpendapat bahwa wali hakim/muhakkam bisa bertindak sebagai wali tatkala tidak ada penghalang pernikahan, tidak ada wali, atau ada wali namun adhal. Jumhur ulama' juga berpendapat memperhatikan urutan wali nikah, jika wali nasab ada maka itu yang digunakan tanpa harus menggunakan wali yang ada dibawahnya. Pernikahan yang penulis teliti secara tegas tidak sah perspektif hukum islam. Secara hukum positif. Jika ditinjau menggunakan hukum positif pernikahan yang tersebut diatas juga bisa dihadapkan atas beberapa dasar pertimbangan, pertimbangan tersebut dengan menggunakan kompilasi hukum islam, UU No. 16 tahun 2019 dan aturan lain yang berkaitan. Berdasarkan ketentuan Pasal 2 ayat (1) dan (2) UU No.1 tahun 1974 Jo. 
Pasal 4 dan Pasal 5 ayat (1) dan (2) KHI, suatu perkawinan di samping harus dilakukan secara sah menurut hukum agama, juga harus dicatat oleh pejabat yang berwenang. Sedangkan dalam hal perwaliannya adalah dalam Pasal 2 ayat (1) PMA Nomor 2 Tahun 1987 tentang Wali Hakim disebutkan sebab-sebab perpindahan dari wali nasab ke wali hakim, senada dengan yang terdapat dalam Kompilasi Hukum Islam pasal 23 ayat (1), hanya redaksinya yang sedikit berbeda, dan dalam UU no 1 tahun 1974 pasal 1 poin b, yang membahas tentang siapa yang berhak menjadi wali hakim, jadi perkawinan tersebut adalah tidak sah dimata hukum positif.

\section{DAFTAR PUSTAKA}

Abdul, Manan, Aneka Masalah Hukum Perdata Islam Di Indonesia, Jakarta: Kencana, 2017

Abdurrahman, Kompilasi Hukum Islam, Jakarta: Akademi Pressindo, 2010

Afandi, Ali, Hukum Waris, Hukum Kleuarga, Hukum Pembuktian, Jakarta: Rineka Cipta, 1997

Ali al-Syuwaisyi, Syaikh Muhammad Hafizh, Tuhfah al-'Urusy wa bil Hajah alNufus, terj. Abdul Rosyad Shiddiq, Kado Pernikahan, Jakarta; Pustaka alKautsar, 2005

Al-Jaziri, Abdur Rohman, Fiqih 'Ala Madzahibil Arba'ah, Jilid; 4, Kairo: Darul Haditst, 2004

Al-Marbawi, Muhammad Idris, Kamus al-Marbawi, Surabaya: Dar al-Ihya, t,.t

Al-Mughniyah, Muhammad Jawad, Fiqih Lima Madzab, Jakarta: Lentera, 2011

Al-Syatibi, Ishaq, al-Muwafaqat fi Ushul al-Syari'ah, Juz;II, Beirut: Dar al-Kutb al-'Ilmiyah, t,.t

Asy-Syaukani, Nail al-Autar, Mesir: Mustafa al-Babi al-Halabi wa-Auladuhu, t.t. Bahreisy, Hussein, Pedoman Fiqih Islam, Surabaya: Al-Ikhlas, 1981 
Bakri A, Rahman dan Ahmad Sukardja, Hukum Perkawinan Menurut Islam, Undang-Undang dan Hukum Perdata, Jakarta: PT. Hidakarya Agung, 1981

Bin Ats'ats al-Sijistani, Abu Daud Sulaiman, Sunan Abû Dâud. Libanon: Dar alFikr 1424H

Dawud, Abu, Sunan Abu Dawud, juz. II; Beirut:Dar al-Kutub al- 'Alamiyah

Departemen Agama RI, Al-Qur'an dan Terjemah Yayasan Penyelenggaraan Penerjemah atau Penafiran Al-Qur'an, Jakarta: Bumi Restu, 1979

Dapertemen Agama RI, Kompilasi Hukum Islam, Jakarta : Karya Anda, 2000

Depdikbud, Kamus Besar Bahasa Indonesia, Jakarta: Balai Pustaka, 1994

Hasan, Mustofa, Pengantar Hukum Keluarga, Bandung : Pustaka Setia, 2011

Hartono, Kamus Praktis Bahasa Indonesia, Jakarta : Rineka Cipta, 1996

Junaedi, Dedi, Bimbingan Perkawinan, Cet; 1, Jakarta: Akademika Pressindo. 2000

Munawwir, Ahmad Warson. Kamus al-Munawir, Jogjakarta: Pondok Pesantren al-Munawwir, 1984

Ni'an Sholeh, Asrorun, Fatwa-Fatwa Masalah Pernikahan dan Keluarga, Jakarta: Graha Pramuda, 2008

Soemiyati, Hukum Perkawinan dan Undang-undang Perkawinan, UndangUndang no. 1 tahun 1974 tentang Perkawinan, Yogyakarta: Liberty, 1986

Soimin, Soedaryo, Hukum Orang dan Keluarga, Perspektif Hukum Perdata Barat/BW, Hukum Islam dan Hukum Adat, Jakarta: Sinar Grafika, 2002

Suma,Muhammad Amin, Hukum Keluarga Islam di Dunia Islam, Jakarta: PT Raja Grafindo Persada, 2005

Supriadi, Dedi, Fiqih Munakahat Perbandingan, Bandung : Pustaka Setia, 2009

Matori, Imam Masjid, wawancara, Tolai, 1 juli 2021

Komarudin, Tokoh Agama, Wawancara, 1 juli 2021

Imam Nasrowi, Imam Masjid Tolai, wawancara, Tolai, 2 juli 2021

Zyad, Informan, wawancara, Tolai, 7 juli 2021

K.S, Informan, wawancara, Tolai, 7 juli 2021 
Zahra latifa,Informan, wawancara, Tolai, 7 juli 2021.

Maduri , Informan, Wawancara, Tolai, 8 Juli 2021.

Komarudin, Informan, wawancara, Tolai, 9 juli 2021

Rosmiati, Informan, Wawancara, Tolai, 9 juli 2021 